\title{
Applying SAVI Approach To Improve Exposition Writing Skills In 5th Grade Students of Penabur Christian Elementary School 6
}

\author{
Merinda1,a, Zulela1,b, Arita Marini1,c \\ ${ }^{1}$ Postgraduate Basic Education, Universitas Negeri Jakarta, Jl. Rawamangun Muka, Jakarta Timur 13220, Indonesia \\ a merinda.tarigan@bpkpenaburjakarta.or.id; b zulelams@yahoo.co.id; c aritamarini@unj.ac.id \\ ${ }^{*}$ Corresponding Author \\ Whatsapp number:
}

How to Cite : Merinda, M., Zulela, Z., Marini, A. (2019). Applying SAVI Approach To Improve Exposition Writing Skills In 5th Grade Students of Penabur Christian Elementary School 6. International Journal for Educational and Vocational Studies, 1 (6), 614-618

\section{ARTICLE HISTORY}

Received:3 June 2019

Revised: 23 July 2019

Accepted: 20 September 2019

\section{KEYWORDS}

Exposition Writing,

SAVI Approach,

Classroom Action Research

\begin{abstract}
This study aims to improve exposition writing skills of the 5th grade students through the application of the SAVI approach (Somatic, Auditory, Visual and Intellectual) in learning. This study is an action research carried out at SDK 6 Penabur North Jakarta. The research subjects were 5th grade students, amounting to 35 students. The implementation of the study was divided into two cycles, each cycle carried out three and four meetings. Data analysis techniques were carried out with qualitative descriptive techniques. The success of this study was seen from two criteria, namely the observation sheet applying the SAVI approach and increasing the results of exposition writing skills. The results of the study obtained are the application of the SAVI approach to make students actively move and search for their own information, students are increasingly active in group learning, creation of written and product made by students and able to find their own knowledge and skills. The increase in the results of exposition writing skills is also seen in the initial cycle and is increasing in cycle 2 . This can be seen from the initial percentage of students who have not completed the task of exposition writing skills by $68 \%$, then the percentage results in the first cycle are $45.7 \%$ and in the end of the second cycle students who obtained incomplete results were only $25.7 \%$. Overall at the end of the second cycle all aspects and criteria for exposition writing experienced a significant increase.
\end{abstract}

This is an open access article under the CC-BY-SA license.

\section{INTRODUCTION}

The determination of the 2013 curriculum is an improvement from the previous curriculum. One of the improved aspects in the 2013 curriculum is the Graduate Competency Standard (SKL). SKL is "criteria regarding the qualifications of graduates' abilities which include attitudes, knowledge, and skills" (Nuh, 2013). SKL contains three domains, namely attitudes, knowledge and skills. These three domains are interrelated and integrated. "Indonesian Language in the 2013 Curriculum is not only a communication tool, but as a carrier of knowledge" (Hamad, 2013). The problems of Indonesian children's writing competence are often discussed in several mass media articles, especially after the release of the 2015 PISA (Program for International Student Assessment) results issued by the Organization for Economic Cooperation and Development (OECD). Indonesia is ranked 64 th out of 72 countries surveyed (Education, 2015).
The challenge of increasing children's competence is faced with several things. First, the lack of understanding of what is learned (comprehensive). Second, the inability to express ideas and frame arguments or the essence of what is learned. Furthermore, based on the researchers' observations and preliminary observations in the field, in the fifth grade of the Christian Elementary School 6 PENABUR, Kelapa Gading North Jakarta, the characteristics of fifth grade students in SDK 6 PENABUR generally are active, easy to lose focus, easily bored, tend to be lazy to read long paragraphs, and less interested in the Indonesian language. This can be seen from the data of race achievements in the last 3 years in schools, which showed that only about $5 \%$ of students participated in the Indonesian language competition. It is different from the fields of Mathematics and Natural Sciences which have very remarkable achievements both nationally and internationally. 
While based on the results of observations in the class during the Indonesian language lesson, students in class $\mathrm{V}$ had difficulty using the correct sentence structure in writing expositions to the type of observation report. These difficulties include choosing words and stringing words into a complete sentence and using standard language. Difficulties in developing ideas or information and facts obtained from observations into written form. In addition, spelling errors are often found so that writing is very difficult to understand.

In Indonesian language lessons for class $\mathrm{V}$ students at SDK 6 PENABUR the problem commonly found is that students still face a number of problems, including the use of sentences that are less effective, difficult to express ideas because of lacking of word choices to make sentences, less able to develop ideas regularly and systematic. Second, lack of mastery of micro language skills, such as the use of punctuation, writing rules, compilation of sentences with the correct structure, to the preparation of paragraphs.

Third, the difficulty of the teacher to find writing learning methods that are in accordance with the conditions and abilities of students, because teachers tend to use the same method continuously to teach writing and ultimately make students less interested in writing. Fourth, the lack of writing exercises given to students, because the lesson time is divided to teach other skills.

Based on the above problems, causing writing expositions of grade 5 students is still fairly low. All these problems must be followed up by the teacher, so as not to develop into a basic problem and make the ability in other lessons also decrease.

The role of the teacher here is very important in directing learning activities in Indonesian. Because students have not been able to actualize their abilities in making exposition reports to the fullest. Moreover, Christian Elementary School 6 PENABUR Kelapa Gading, North Jakarta is a school with a bilingual program that uses English as an introduction to science and Mathematics lessons and daily communication more often using English.

One effort that needs to be done by the teacher in helping students overcome the difficulties of writing exposition is to design learning in the classroom with interesting, dynamic, and full variation methods according to the characteristics of students who have different learning styles.

The SAVI learning approach (Somatic, Auditory, Visual and Intellectual) is expected to help improve students' abilities in writing exposition.

The selection of the SAVI approach is because learning methods that emphasize student involvement in the form of actions emphasize speaking and listening to students, learning that emphasizes seeing and observing or observing activities, and encourages students to think and solve problems and through the four stages of the SAVI process learning becomes fun (Lestari, Azizah, Unesa, \& Worksheet, 2012). The application of the SAVI approach is expected to improve students' abilities in learning Indonesian more optimally.

Based on previous research, what has been done by Asep Samsudin regarding the improvement of the ability to write news expositions and illustration expositions of class V students through the integrated cooperative learning model of reading and writing in 2011/2012, with the results of research showing that the ability to write expositions and exposition illustrations of students who following learning through an integrated cooperative learning model of reading and writing has increased significantly than students who take conventional learning. The research by Herwulan Irine Purnama regarding the improvement of exposition writing skills using the mind map method in learning Indonesian in grade $\mathrm{V}$ of Pontianak City Elementary School 14 increased after using the mind map method in writing exposition. So the SAVI method (Somatic, Auditory, Visual and Intelectual) is expected to improve exposition writing skills.

\section{METHODS}

This study aims to prove empirically whether the application of the SAVI approach (Somatic, Auditory, Visual, Intellectual) is able to improve the exposition writing skills of fifth grade students of SDK 6 Penabur North Jakarta. This action research was carried out at the 6 Penabur Kelapa Gading Christian Elementary School, North Jakarta. The time of the study is conducted in the second semester of the 2018/2019 academic year starting from May to July of 2019. Research Methods and Action Intervention Design.

\section{Action Intervention Method}

The type of research used in this research is Classroom Action Research. The class action research model used was the Kemmis and McTaggart model.

\section{Action Intervention Design}

Design of Cycle Action/Design Interventions The research used in this study was the Kemmis and McTaggart cycle model which was carried out through the cycle assessment process, which consisted of 4 stages: action planning, action, observation, and reflection.

\section{Subjects involved in research}

The subjects in this study were fifth grade students of SDK 6 PENABUR North Jakarta, which amounted to 35 students. In the 2018/2019 Academic Year. Participants in this study were principals and colleagues who acted as observers for the continuity of learning. The two collaborators acted as respondents or informants.

\section{RESULT AND DISCUSSION}

After observing and obtaining pre-cycle results, visualization of the results of class $\mathrm{V}$ writing skills was obtained: 


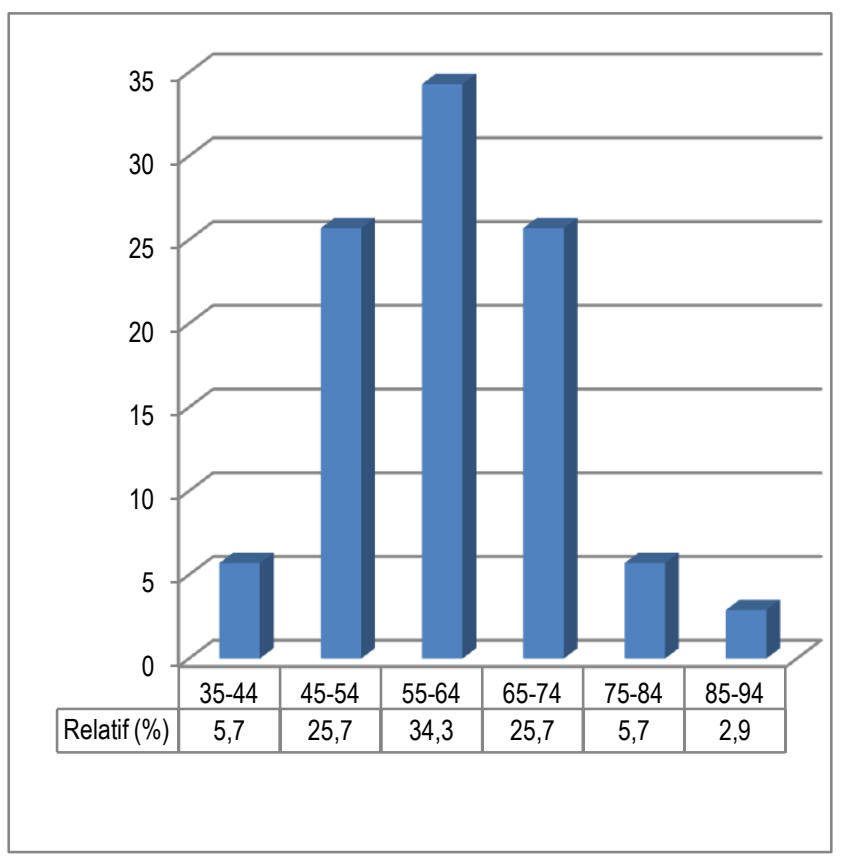

Diagram 1. Results of Pre-cycle Exposition Writing Skills

Based on the explanation above, it can be concluded that the exposition writing skills of the fifth grade students of SDK 6 PENABUR are still low and there is a need for action towards learning which can have a positive impact on improving exposition writing skills.

\section{Implementation of Cycle I}

Data The results of exposition writing skills show the highest gain in the 61-80 value of 27 students with a total percentage of $77.13 \%$. Then the students who obtained high results were described as numbering 5 students with a percentage of only $14.29 \%$. To get a visual picture of the results of exposition writing skills, they are presented in the form of a diagram as follows.

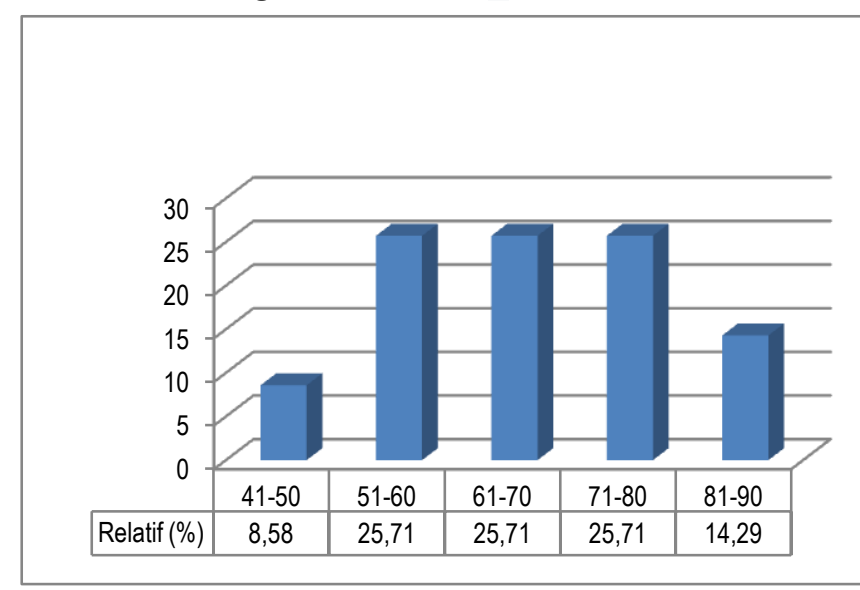

Diagram 2. Results of Cycle I Exposition Writing Skills

The results of exposition writing skills show the highest gain at 71-80 as many as 13 students with a total percentage of $37.15 \%$. Then the students who obtained high results were described to increase to 9 students with a percentage of only $25.71 \%$. To get a visual picture of the results of exposition writing skills, they are presented in the form of a diagram as follows.

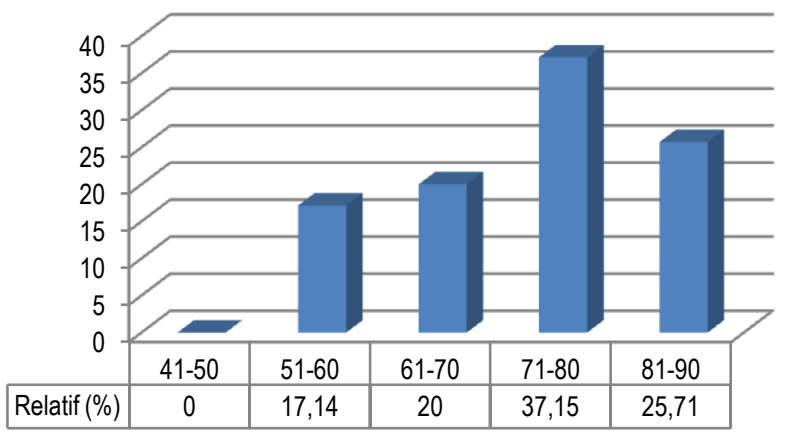

Diagram 3. Results of Cycle II Exposition Writing Skills

The results of exposition writing skills in class V students have met the expected targets. So the study of the application of the SAVI approach to improve exposition writing skills in class $\mathrm{V}$ students was stopped in cycle II. The results in the table above show that there were 26 students who completed their grades above the KKM with the percentage of 74.29 percent exceeding the initial target set at $70 \%$.

The results of the study were an increase in exposition writing skills by applying the SAVI approach to learning. Improvement of exposition writing skills in the first cycle is known as 19 students have completed reaching KKM school assessment with a percentage of $54.3 \%$ and as many as 16 students with a percentage of $45.7 \%$.

Improvement of exposition writing skills in the first cycle has not yet reached the target where student scores are still below the average minimum completeness criteria. Through observers' observations, it was also found that in the first cycle the application of the SAVI approach to teacher activities only reached $65 \%$ and the activity of new students reached $60 \%$.

The results of exposition writing skills by applying the SAVI approach in the second cycle obtained results as many as 26 students had completed reaching the minimum completeness criteria or with a percentage of $74.3 \%$. This achievement has exceeded the original target of only $70 \%$. Then it can be concluded that the implementation of the action in the second cycle has fulfilled the specified target and the study of the application of the SAVI approach to improve exposition writing skills in class V SDK 6 PENABUR North Jakarta was stopped in this second cycle. This proves that the application of the SAVI approach can improve exposition writing skills in class V SDK 6 PENABUR North Jakarta. 


\section{CONCLUSION}

Based on observations during the two cycles and discussion of the results of the action, several conclusions can be presented as follows. First, every stage of preparation in starting learning, students are always given positive suggestions through useful statements through the words of the teacher or fellow students, arousing students' interest through physical movements such as motion and song, applause, lines lined up outside the classroom and other interesting activities.

Second, material delivery activities or core activities are carried out with the student center method where the teacher helps teach or find new material in an interesting, relevant and fun way and involves the senses of students so that they can adapt to the various learning styles of each student. The thing that is done by the teacher who also acts as a researcher is designing exposition writing learning by observing the real phenomena that exist around students, involving the whole brain and body with interactive presentation activities, group discussions, conducting science workshop activities where students can observe and try some experiments which are then recorded as information, even to the stage of producing work through the bento workshop activities. .

Third, at the stage of writing practice or reinforcement. Students are directed to integrate knowledge or information obtained through interactive dialogue activities in small groups, the creation of a product or work result, peer tutoring, continuous training, to obtain a learning atmosphere that makes students communicative and actively moves physically, and expresses opinions verbally and written.

\section{REFERENCES}

Abidin, Y. (2015a). Pembelajaran Multiliterasi Sebuah Jawaban atas Tantangan Pendidikan Abad Ke-21 dalam Konteks Keindonesiaan - Hlm 16-17. Bandung: PT. Refika Aditama.

Abidin, Y. (2015b). Pembelajaran Multiterasi Sebagai Sebuah Jawaban Atas tantangan Pendidikan Abad 21. Bandung: PT Refika Aditama.

Alwasilah, \& A.Chedar. (2005). Pokoknya Menulis (1 ${ }^{\text {st }}$ ed.). Bandung: Kiblat Buku Utama.

Arikunto, \& Suharsimi. (2013). Dasar-dasar Evaluasi Pendidikan. Jakarta: Bumi Aksara.

Arundati, H., \& Sitepu, B. . (2010). Jurnal Pendidikan PENABUR. Jakarta: Badan Pendidikan Kristen Penabur.

Asrin, H., Gaol, L., \& Siregar, M. (n.d.). The Effect Of Applying Somatic Auditory Visual Intellectual ( Savi) Method On Students'.

B.Hurlock, E. (2002). Psikologi Perkembangan. Jakarta: Erlangga.

Bachman's. (2001). Introduction to Action Research (p. 14). SAGE Publications, Inc.

Barbara J.Everson. (n.d.). Vygotsky and the teaching of writing.pdf.
Baumfield, V., Hall, E., \& Wall, K. (2009). Action Research di Ruang Kelas (first). Jakarta: PT Indeks.

Bobi De Porter. (2002). Quantum Learning: Membiasakan belajar Nyaman dan Menyenangkan. Bandung: Kaifa.

Craig A.Mertler. (2009). Action Research: Teacher as Researcher in the Classroom. London: SAGE Publications, Inc.

Desmita. (2014). Psikologi Perkembangan Peserta didik. Bandung: Remaja Rosdakarya.

Djuanda, D. (2010). Penilaian dalam Pembelajaran Bahasa Indonesia di Sekolah Dasar. Researchgate.Net, 15. Retrieved from https://www.researchgate.net/.../260302316_Penilaian _dalam_Pemb...

Education, E. I. N. (2015). PISA (Vol. I).

Ekawarna. (2011). Penelitian Tindakan Kelas. Jakarta: Gaung Persada.

Emzir. (2007). Metodologi Penelitian. Jakarta: Rajawali Pers.

Fatima, S. (2012). Teaching Report Writing Skills through Communicative Activities. American International Journal of Contemporary Research, 2(2).

Febri Yatmiko, Eva Banowati, P. S. (2015). Journal of Primary Education. Journal of Primary Education, 1(2), 77-84. Retrieved from http://journal.unnes.ac.id/sju/index.php/jpe

Finoza, L. (2013). Komposisi Bahasa Indonesia: Untuk Mhasiswa Nonjurusan Bahasa (18th ed.). Jakarta: Diksi Insan Mulia.

George, N. A., \& Craven, M. (2010). Using Action Research to Enhance Teaching. Evaluation, (April 2011). https://doi.org/10.1080/0260293032000059603

Glover, D., \& Law, S. (2005). Improving Learning. Jakarta: PT Grasindo.

Greadler, M. E. (2011). Learning and Instruction. Jakarta: Kencana.

Hamad, I. (2013). Kurikulum 2013: Momentum memuliakan Bahasa Indonesia. Pendidikan, (Kurikulum 2013). Retrieved from http://magister-pendidikan.blogspot.com/2013/11/kuri kulum-2013-momentum-memuliakan.html

Hasani, A. (2005). Ikhwal Menulis. Serang: Universitas Sultan Agung Tirtayasa.

Henri Guntur Tarigan. (2008). Menulis sebagai keterampilan berbahasa. Bandung: Angkasa.

James Mc Kernan. (2006). Curriculum Action Research A Handbookof Methods and Resources for the Reflective Practitioner (Second). London: Routledeg Taylor \& Francis Group.

Journal, I., Language, E., Vol, T., Centre, E., \& Uk, D. (2014). Teaching Writing Skills in English: Involvement of Students in the Asessment and Correction of their own Errors, 3(1), 68-73.

Kasupardi, E., \& Supriatna. (2012). Pengembangan Keterampilan Menulis. Jakarta: Multi Kreasi Satudelapan.

Kemendikbud. (2014). Buku Guru Bahasa Indonesia Wahana Pengetahuan SMP/Mts Kelas VII. 
Kementrian Pendidikan dan Kebudayaan.

Kemmis, S., \& McTaggart, R. (1998). The Action Research Planner (third). Victoris: Deakin University.

Kurniawan, H. (2015). Pembelajaran Kreatif Bahasa Indonesia Kurikulum 2013 - Hlm. 39-41. Jakarta: Prenadamedia Group.

Lestari, A., Azizah, U., Unesa, S. F., \& Worksheet, S. S. (2012). Development Of Science-Chemitry Student Workheet Oriented Somatic, Auditory, Visual, And Intellectual ( Savi ) In The Topic Matter Changes For Junior High, 1(1), 41-46.

M.Mclerney, D., \& Mclerney, V. (1998). Educational Psychology. Australia: Prentice Hall.

Meier, D. (2000). The Accelerated Learning Handbook. Learning.

Menteri Pendidikan dan Kebudayaan. (2012). Permendikbud No 66 Tahun 2013 tentang Standar Penilaian Pendidikan, 2011, 1-6. https://doi.org/10.1016/j.metabol.2009.10.012

Muhammad Javed. (2013). A Studt of Students Assesment Writing Skill of the English Language. International Journal of Instruction, 6, 130.

New, M. (2002). Developmental psychology: Childhood and adolescence. Behaviour Research and Therapy (Vol. 28). https://doi.org/10.1016/0005-7967(90)90171-e

Nuh, M. (2013). Salinan Permendikbud Nomor 54, 2011. Retrieved from http://luk.staff.ugm.ac.id/atur/bsnp/Permendikbud542013SKL.pdf

Nurgiyantoro, B., Universitas, F. B. S., \& Yogyakarta, N. (2004). Penilaian Berbahasa Berbasis Kompetensi. Yogyakarta:BPFE.

Oleh, S. P., Prodi, N. N. I. M., Astrini, L., Bahasa, P., \& Indonesia, S. (2013). Pengembangan Bahan Ajar Menulis Petunjuk, 448-462.

PENABUR Jakarta. (2005). Jurnal Pendidikan Penabur (15 $5^{\text {th }}$ ed.). Jakarta: Badan Pendidikan Kristen Penabur.

Priyatni, E. T. (2014). Desain Pembelajaran Bahasa Indonesia Dalam Kurikulum 2013 - Hlm. 7. Jakarta: Bumi Aksara.

Russel, L. (1999). The Accelerated Learing Fieldbook. San Fransisco: Jossey Bass.

Sanjaya, W. (2013). Penelitian Pendidikan Jenis Metode dan Prosedur. Jakarta: Kencana.

Santrock, J. W. (2011). Educational Psychology (fifith).

Satini, R. (2018). Kemampuan Menulis Karangan Eksposisi Dengan Menggunakan Teknik Mind Map Siswa Kelas X Sma Negeri 14 Padang. Gramatika STKIP PGRI Sumatera Barat, 2(2). https://doi.org/10.22202/jg.2016.v2i2.976

Scott, D., \& Marlene Morrison. (2006). Key Ideas in Educational Research. London: Continuum International Publishing Group.

Susi, A., \& Puspita, S. (2016). Teks Eksposisi, 1(16), 1-19.

Tarigan, H. G. (2008a). Menulis Keterampilan Berbahasa. Bandung: Angkasa Bandung.
Tarigan, H. G. (2008b). Menulis Sebagai Suatu Keterampilan Berbahasa - Hlm. 1. Bandung: Angkasa.

Wholey, J. S. (2010). Handbook of Practical Program Evaluation, 3, 429.

wikipedia. (n.d.). eksposisi. Retrieved from https://id.wikipedia.org/wiki/Eksposisi

Yamin, M. (2011). Paradigma Baru Dalam Pembelajaran. Jakarta: Gaung Persada.

Yanti, P. A. (2013). Menyampaikan Gagasan Lewat Tulisan. Pelitaku, 1.

Zulela, \& Saleh, H. (2013). Terampil Menulis di Sekolah Dasar. Tangerang: Pustaka Mandiri. 